\title{
PREDNISONE IN RHEUMATOID ARTHRITIS: METABOLIC AND CLINICAL EFFECTS
}

\author{
BY \\ L. EMMERSON WARD, HOWARD F. POLLEY, MARSCHELLE H. POWER, \\ HAROLD L. MASON, CHARLES H. SLOCUMB, AND PHILIP S. HENCH \\ Mayo Clinic and Mayo Foundation, ${ }^{*}$ Rochester, Minn.
}

The initial reports (Hench, Kendall, Slocumb, and Polley, 1949; Sprague, Power, Mason, Albert, Mathieson, Hench, Kendall, Slocumb, and Polley, 1950; Hench and others, 1950) of the antirheumatic potency of cortisone emphasized the fact that excessive doses produced not only desirable but also certain undesirable effects. At that time (1949), we expressed our hope and belief that analogues superior to cortisone would be discovered. Since then, at least seven more cortisone-like steroids have been found useful clinically; these include hydrocortisone, 9-alpha-fluorohydrocortisone (Fludrocortisone), prednisone, prednisolone, a compound whose structure is 9-alpha-fluoro, delta 1-hydrocortisone, and the two most recent additions, namely triamcinolone and 6-methyl, delta 1-hydrocortisone.

Each of these eight compounds has distinctive characteristics. Cortisone is the least costly to prepare synthetically; it is still useful in many cases and preferable in some. Hydrocortisone, apparently the major product of the normal human adrenal cortex, has proved to be superior to cortisone in local, especially intra-articular, administration. Fludrocortisone possesses a greatly enhanced antirheumatic effect (about ten times greater than that of cortisone, milligram for milligram); however, its effect on the retention of sodium and chloride and the excretion of potassium is even more enhanced. Thus, fludrocortisone is especially useful in the adrenal insufficiency of Addison's disease and when used in ointments for certain dermatological conditions, but the qualities that make it superior to cortisone or hydrocortisone in the management of Addison's disease interfere with its usefulness for rheumatic patients. Nevertheless, its production represented a distinct advance, because it demon-

* The Mayo Foundation, Rochester, Minnesota, is a part of the Graduate School of the University of Minnesota. strated that chemists could alter the steroid molecule so as to prepare synthetic compounds with even more selective effects. This paved the way for the dissociation of one effect from another, so that one or more of these effects could be enhanced relatively.

The chemical structure of prednisone (delta 1-cortisone) and prednisolone (delta 1-hydrocortisone) differs from that of cortisone and hydrocortisone, respectively, only in the possession of a double bond (hence the designation "delta") between the first and second carbon atoms in ring $A$ of the molecule (Fig. 1, overleaf). It is this slight change that invests these synthetic cortisone-like steroids with an increased antirheumatic potency and a decreased effect on the metabolism of electrolytes when compared, milligram for milligram, with cortisone and hydrocortisone. It was hoped that a similar alteration of the 9-alpha-fluorohydrocortisone molecule might lessen the pronounced effect of that compound on electrolytes and perhaps might even enhance its great antirheumatic effect. Such did not prove to be the case, however, and the aforementioned 9-alpha-fluoro, delta 1-hydrocortisone proved to be similar in effect to 9-alpha-fluorohydrocortisone (Thorn, Renold, Morse, Goldfien, and Reddy, 1955; Bunim, 1957).

Triamcinolone has the chemical structure 16 alphahydroxy, 9-alpha-fluoro, delta 1-hydrocortisone. Its rheumatic potency appears to be approximately that of prednisone (Hellman, Zumoff, Schwartz, Gallagher, Berntsen, and Freyberg, 1957). Medrol, which is the afore-mentioned 6-methyl, delta 1hydrocortisone, also is said to have about the same anti-rheumatic potency as prednisone (Glenn, Stafford, Lyster, and Bowman, 1957). Whether these two newest steroids will have additional practical therapeutic advantages remains to be determined by further clinical studies. 


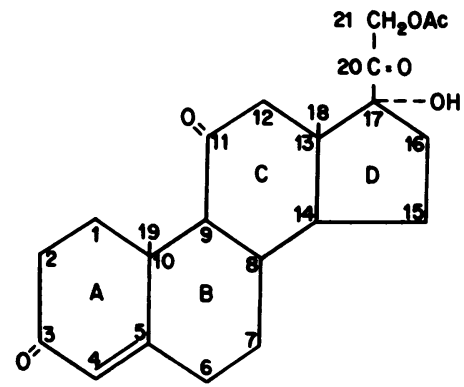

Cortisone ocetate

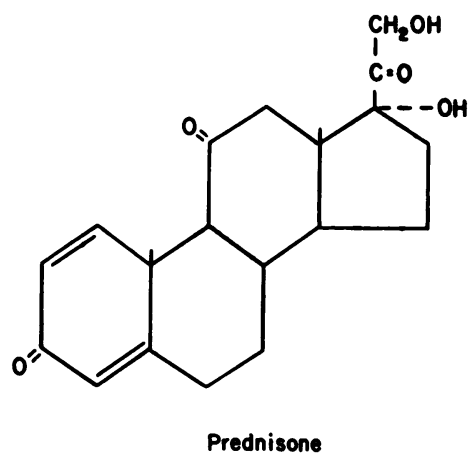

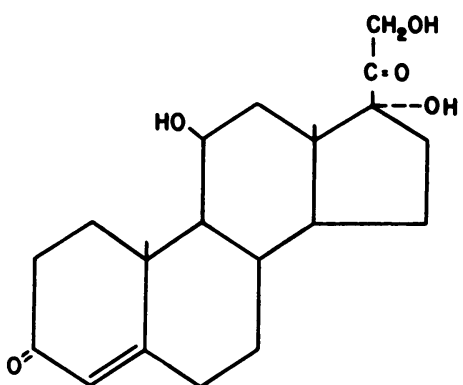

Hydrocortisone

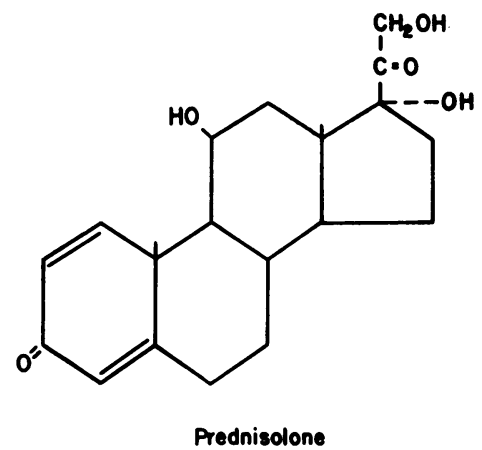

Fig. 1.-Structural formulae showing relationship between cortisone and prednisone, and between hydrocortisone and prednisolone.

\section{Present Study}

We have studied the antirheumatic and other clinical effects of prednisone and prednisolone on many patients who had rheumatoid arthritis. In three such cases, we also made special studies concerning the metabolic effects of prednisone and in two of these three cases we compared these effects with those of cortisone or hydrocortisone.

The metabolic balances of sodium, chloride, potassium, total nitrogen, calcium, and inorganic phosphorus were studied by procedures and methods described previously (Sprague and others, 1950; Hench and others, 1950; Ward, Polley, Slocumb, Hench, Mason, Mattox, and Power, 1954; Salassa, Power, Ulrich, and Hayles, 1954). Observations were made on electrolytes, urea, uric acid, proteins, sugar, and various lipids in the blood, and on the urinary excretion of corticosteroids, 17-ketosteroids, uric acid, and creatinine; studies also were made of the erythrocyte sedimentation rate, glucose tolerance, basal metabolic rate, blood pressure, electrocardiograms, and electroencephalograms.

\section{Report of Cases}

Case 1, a 51-year-old woman, who had had severe rheumatoid arthritis for 1 year, received first a constant dose of prednisone, starting on February 27, 1955, and then hydrocortisone; after this, prednisone was given in $₹$ decreasing doses. Initially, $20 \mathrm{mg}$. prednisone per day $ᄋ$ was given orally ( $5 \mathrm{mg}$. every $6 \mathrm{hrs}$ ) for 36 days, after which its use was discontinued for 12 days. Thereafter, $\frac{D}{0}$ hydrocortisone (free alcohol) was administered orally in doses of $80 \mathrm{mg}$. per day $(20 \mathrm{mg}$. every $6 \mathrm{hrs})$ for 24 days. $N$ Then prednisone was again given orally as follows: $20 \mathrm{mg}$. daily $(5 \mathrm{mg}$. every $6 \mathrm{hrs})$ for 6 days; $17.5 \mathrm{mg}$. O daily $(5 \mathrm{mg}$. at 2 a.m., 8 a.m., and 2 p.m., $2.5 \mathrm{mg}$. at $\omega$ 8 p.m.) for 6 days; $15 \mathrm{mg}$. daily ( $5 \mathrm{mg}$. at 8 a.m. and 8 p.m., $2 \cdot 5$ mg. at 2 a.m. and 2 p.m.) for 6 days.

Antirheumatic Effects.-Symptomatic relief was noted $\mathbb{\complement}$ 3 hours after the first dose of prednisone, and objective? improvement was noted within the first 24 hours. Both ${ }^{0}$ progressed rapidly so that by the 36th day of treatment the over-all improvement (loss of the patient's disability) 


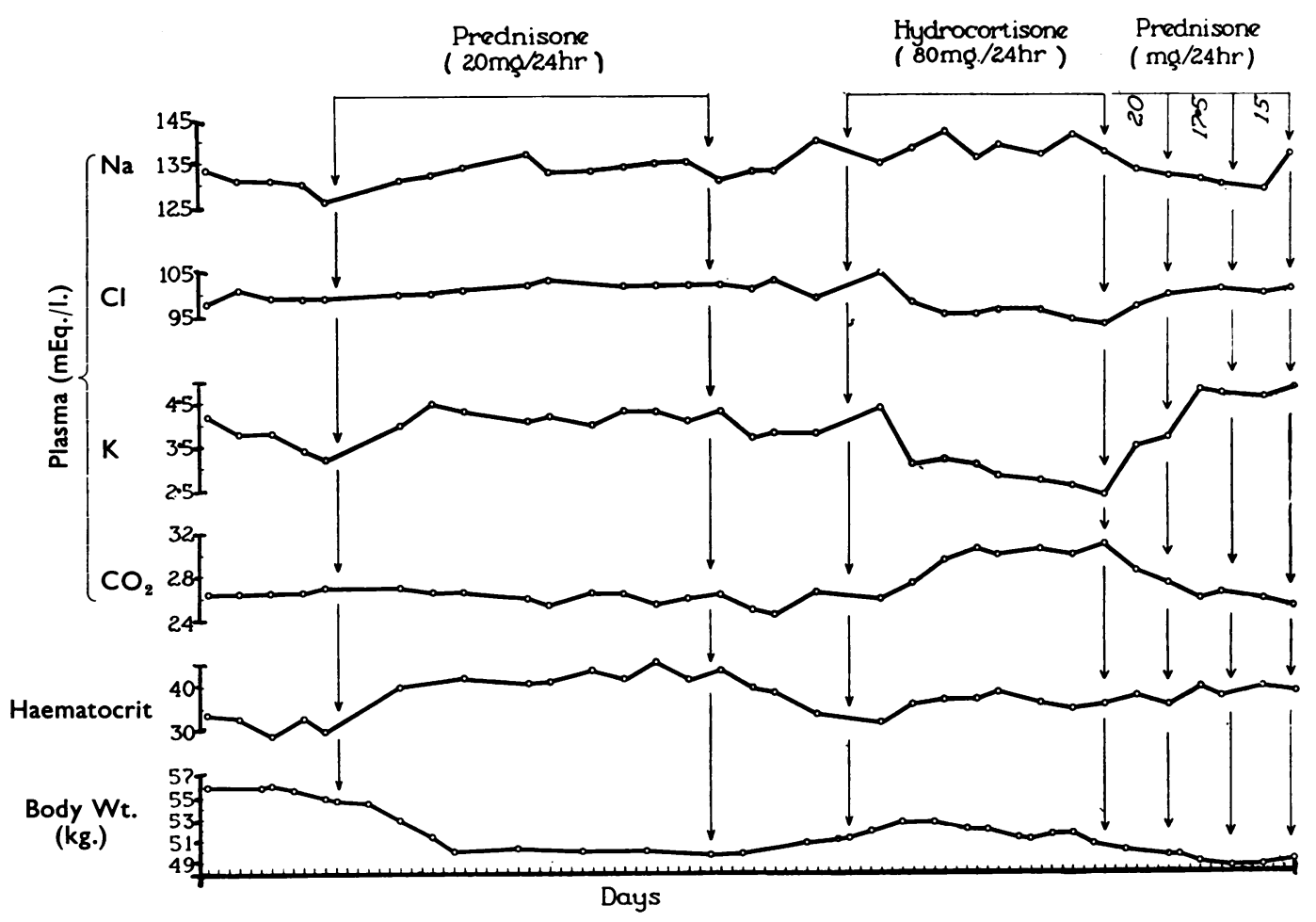

Fig. 2.-Case 1, effect of prednisone and hydrocortisone on concentration of electrolytes in plasma and on haematocrit and body weight.

was rated as 90 per cent. When administration of prednisone was stopped, rheumatoid symptoms and signs recurred rapidly. Hydrocortisone was found, as had been expected from other studies, to be only onefourth as effective, milligram for milligram, as prednisone, $80 \mathrm{mg}$. of the former being the antirheumatic equivalent of $20 \mathrm{mg}$. of the latter. The subsequent use of prednisone in doses of $20 \mathrm{mg}$. per day maintained the same degree of symptomatic relief as $\mathbf{8 0 ~ m g}$. hydrocortisone. The smaller doses of prednisone, namely $17 \cdot 5$ and $15 \mathrm{mg}$. daily, were proportionately less effective, as one might anticipate.

Other Clinical Effects.-The pitting oedema of the lower legs that was present in this patient before treatment, probably from rheumatoid inflammation, decreased notably during both courses of prednisone; the body weight decreased concomitantly (Fig. 2). On the other hand, administration of hydrocortisone led to retention of fluid, with increased oedema, presumably non-inflammatory, and body weight. Neither steroid altered the blood pressure. Both steroids produced transient mild mental stimulation (euphoria, restlessness, insomnia). Obstipation developed during the first course of prednisone. (Its occurrence in this patient and in a few others observed subsequently suggests that this rarely may be a complication of treatment with prednisone.)
Laboratory Data.-The laboratory data are summarized in Table I (overleaf) and Figs 2 to 5.

Additional Sodium Chloride.-To test this patient's tolerance for additional salt, $3 \mathrm{~g}$. sodium chloride was added to the diet from the 25th to the 30th day inclusive of the first course of prednisone. This did not alter the balances or the serum levels of sodium or chloride.

Case 2, a 54-year-old woman, who had had rheumatoid arthritis of moderate severity for 1 year, was given $30 \mathrm{mg}$. prednisone orally per $24 \mathrm{hrs}(7 \cdot 5 \mathrm{mg}$. every $6 \mathrm{hrs}$ ) for 12 days, starting on July 27, 1955; then, after steroids had not been given for 12 days, she received four times as much cortisone, or $120 \mathrm{mg}$. per day orally (30 mg. every $6 \mathrm{hrs}$ ) for 12 days.

Antirheumatic Effects.-The daily dose of $30 \mathrm{mg}$. prednisone afforded 90 per cent. relief of the signs and symptoms of rheumatism, whereas the daily dose of $120 \mathrm{mg}$. cortisone afforded only 80 per cent. relief. With both steroids, the onset of relief was rapid, and disability gradually recurred after treatment was stopped.

Other Clinical Effects.-Both steroids produced moderate insomnia and increased hot flushes.

Laboratory Data.-These are summarized in Table I and in Figs 6 to 9. 
TABLE I

SUMMARY OF EFFECTS OF STEROIDS IN THREE CASES OF RHEUMATOID ARTHRITIS

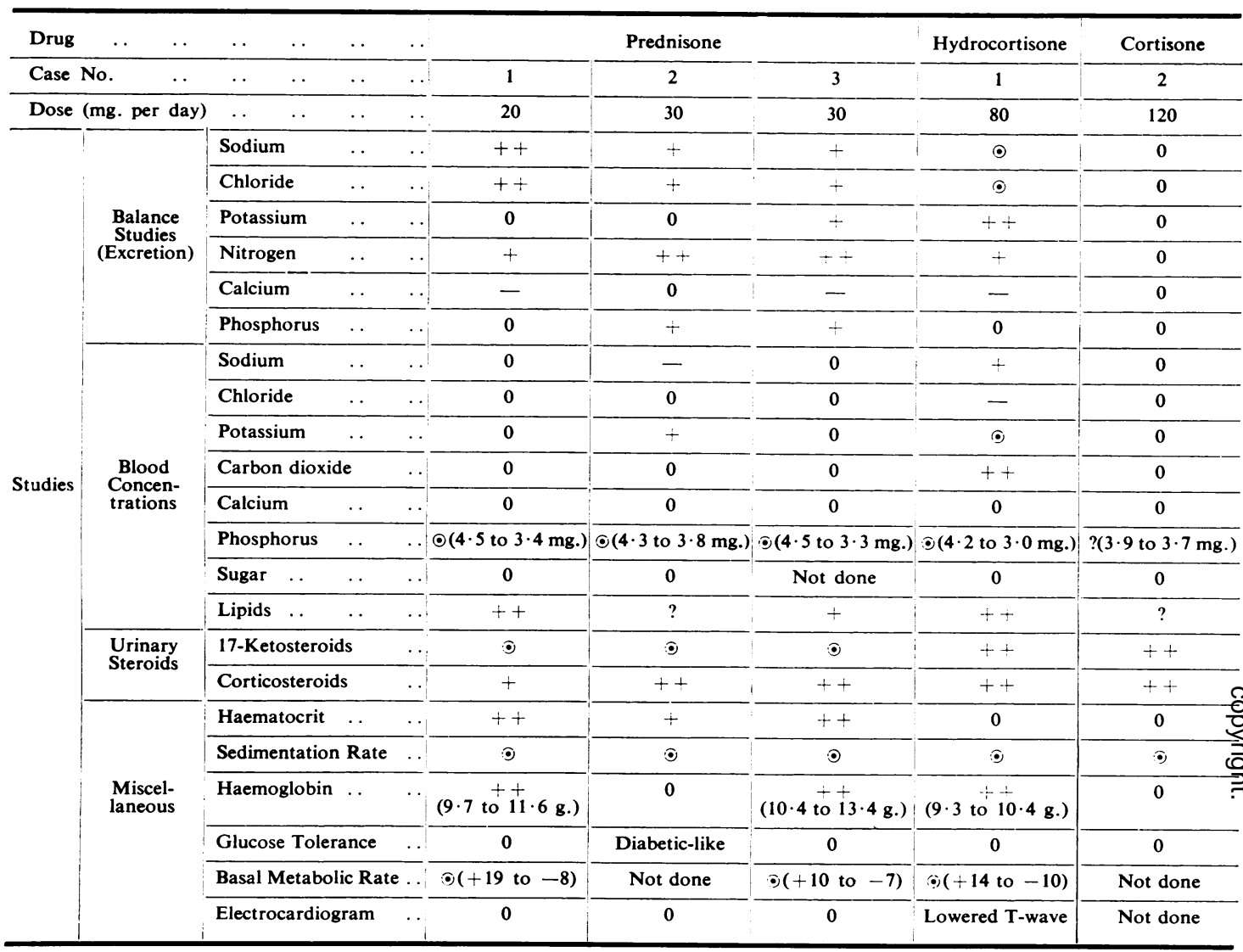

Key to symbols: ++ increase; + slight increase; 0 no change; - slight decrease; $\odot$ decrease from period of previous medication ? uncertain effect.

Case 3, a 61-year-old man, who had had severe rheumatoid arthritis for 1 year, was given prednisone in doses of $30 \mathrm{mg}$. per $24 \mathrm{hrs}(7 \cdot 5 \mathrm{mg}$. every $6 \mathrm{hrs})$ for 24 days, starting on December 25, 1954.

Clinical Results.-The antirheumatic effect of prednisone, first noted 7 hours after the initial dose, became pronounced within 24 hours and progressed rapidly to afford over-all reduction of at least 90 per cent. of the rheumatoid signs and symptoms; this degree of relief was sustained during administration of the steroid. Undesirable clinical effects were not present. The blood pressure was not altered. Body weight decreased by $3.5 \mathrm{~kg}$. during the administration of prednisone (Fig. 10); most of this decrease was apparently caused by urinary loss of sodium, chloride, and water (Fig. 11), although some loss of nitrogen was also involved (Fig. 12). Unfortunately, further planned studies, including subsequent comparison with the effects of cortisone, had to be discontinued after 24 days of administration of prednisone because acute severe diverticulitis developed on the 20th day. Whether the diverticulitis was related to the use of prednisone is uncertain; the signs, symptoms, and surgical pathological findings were indistinguishable from those of diverticulitis in patients who have not been treated with steroids.

Laboratory Data.-These are summarized in Table I and Figs 10 to 13.

\section{Summary of Metabolic and Clinical Data, and Comment}

Antirheumatic Effect.-In Case 1, prednisone was four times as potent as hydrocortisone, milligram for milligram; a daily dose of $20 \mathrm{mg}$. prednisone was the antirheumatic equivalent of a daily dose of $80 \mathrm{mg}$. hydrocortisone, both steroids producing about 90 per cent. relief. In Case 2, prednisone was about four and a half times as effective as 


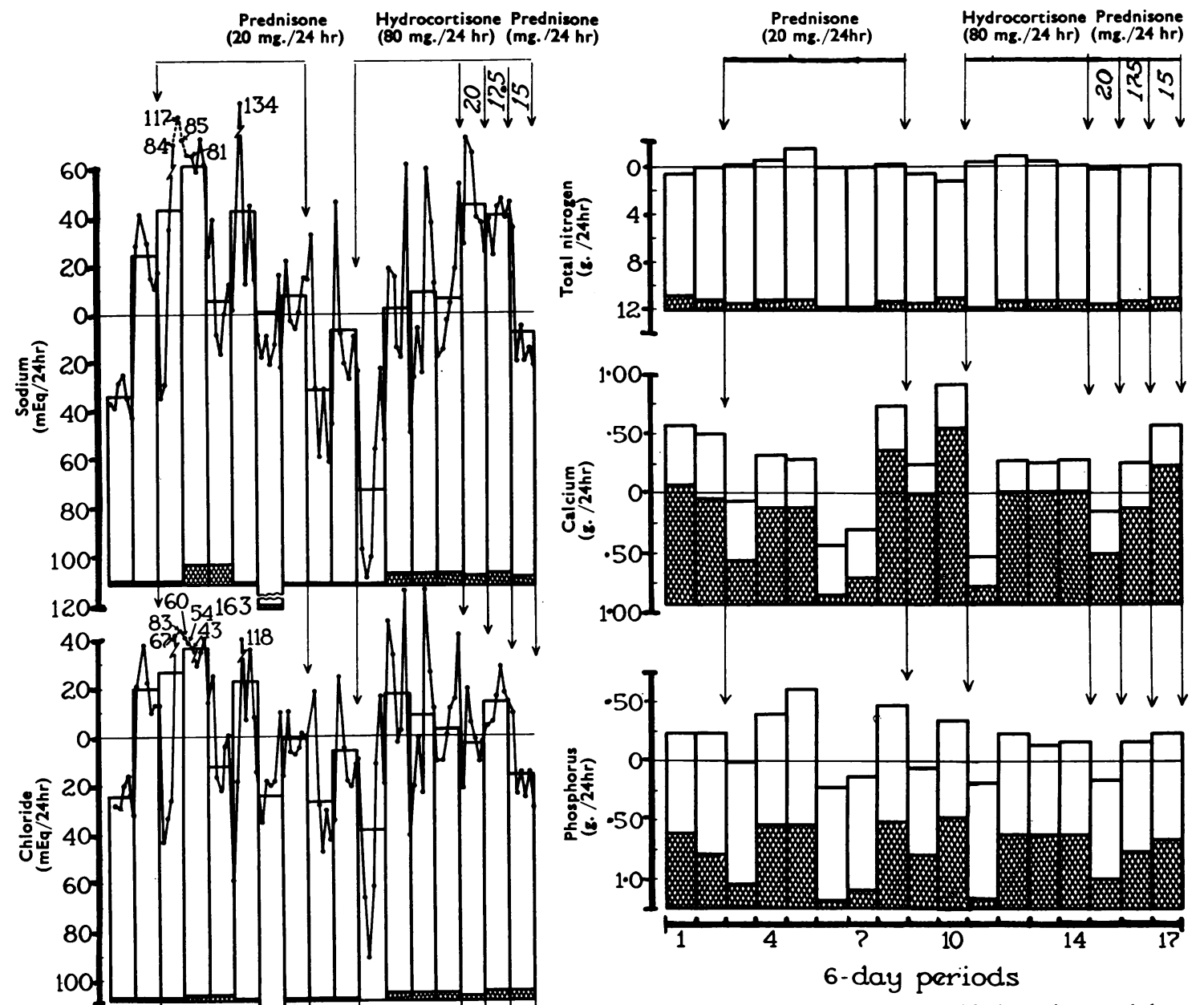

Fig. 4.-Case 1, effect of prednisone and hydrocortisone on balance of total nitrogen, calcium, and inorganic phosphorus.

cortisone; a daily dose of $30 \mathrm{mg}$. prednisone gave 90 per cent. relief, whereas a daily dose of $120 \mathrm{mg}$. cortisone gave only 80 per cent. relief. In Case 3, $30 \mathrm{mg}$. prednisone per day produced 90 per cent. relief, and comparisons with other steroids could not be made.

These results, together with those from numerous other patients whom we have studied clinically, confirm the findings of Bunim, Pechet, and Bollet (1955a) and of Boland (1955; 1956), Bunim and others (1955b), Dordick and Gluck (1955), Bunim, Black, Bollet, and Pechet (1955), Margolis, Barr, Stolzer, Eisenbeis, and Martz (1955), Spies, Stone,

Fig. 3.- Case 1, effect of prednisone and hydrocortisone on balance of sodium, chloride, and potassium.

In Fig. 3 and in subsequent comparable figures, daily intake is measured downward (but not blocked in) from the 0 line, and is represented by the distance from the 0 line to the bottom line of the column. The average daily excretion (faecal, hatched column; urinary, clear column) is charted upward from the bottom line. Each column represents a 6-day period. Each dot represents the daily balance calculated by subtracting from the daily intake the sum of the daily urinary excretion and one-sixth of the faecal excretion for that 6 -day period. $A$ negative balance is indicated when the top of the column or the dot is above the 0 line; a positive balance is indicated by a position below the 0 line. 


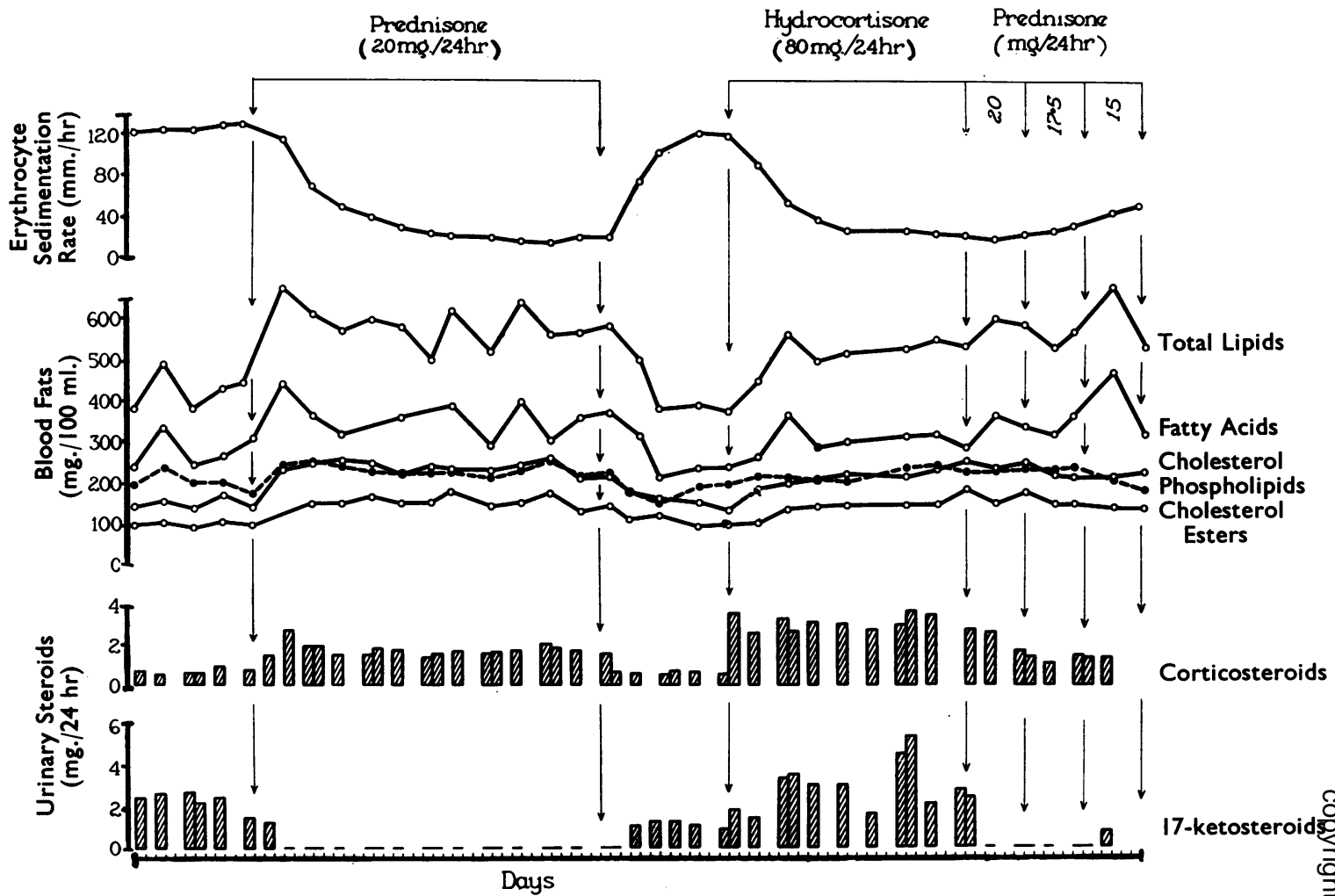

Fig. 5. - Case 1, effect of prednisone and hydrocortisone on erythrocyte sedimentation rate, concentration of blood fats, and urinary excretion of corticosteroids and 17 -ketosteroids.

and Spies (1955), Villa, Ballabio, and Sala (1955), Spies, Stone, López, Tellechea, Toca, Reboredo, and Suárez (1955), Hollander (1955), Cohen, Turner, and Dunsmore (1955) that prednisone has an antirheumatic effect at least four or five times greater than that of cortisone or hydrocortisone, milligram for milligram. We have not observed any qualitative difference between the antirheumatic effects of prednisone or prednisolone and those of cortisone or hydrocortisone.

Undesirable Clinical Effects. - By undesirable sideeffects, we mean effects not required or desired in a particular patient. Prednisone, given briefly to these three patients, produced only minor undesirable clinical effects in the two women. However, prednisone (or prednisolone), given in excessive doses for a sufficient length of time, can produce all the undesirable effects of excessive amounts of cortisone or hydrocortisone, as we and others have observed in other rheumatoid patients treated with these newer steroids. The undesired effects produced by prednisone were approximately the same, milligram for milligram, in the two women; such is not always the case, of course, since different tolerances for prednisone may be found. However, men generally tolerate antirheumatic steroids, including prednisone, better than do women.

The approximately equivalent antirheumatic doses of prednisone (20 mg.) and hydrocortisone $(80 \mathrm{mg}$.) in Case 1 produced about the same degree of undesired side-effects in that patient. Thus, prednisone was about four times as potent as hydrocortisone not only in antirheumatic activity but also in the production of undesired side-effects. The same general relationship obtained between prednisone and cortisone in Case 2.

It is obviously important to compare compounds in equivalent antirheumatic doses when an attempt is made to assess their relative strength with respect to other functions. However, accurate comparison of relative antirheumatic effects, far from being easily accomplished, requires considerable time, care, and a number of suitable patients. It is not difficult, early in the investigation of a new steroid, to be temporarily misled regarding its antirheumatic potency both in general and in individual cases and hence to be misled secondarily as to its relative 


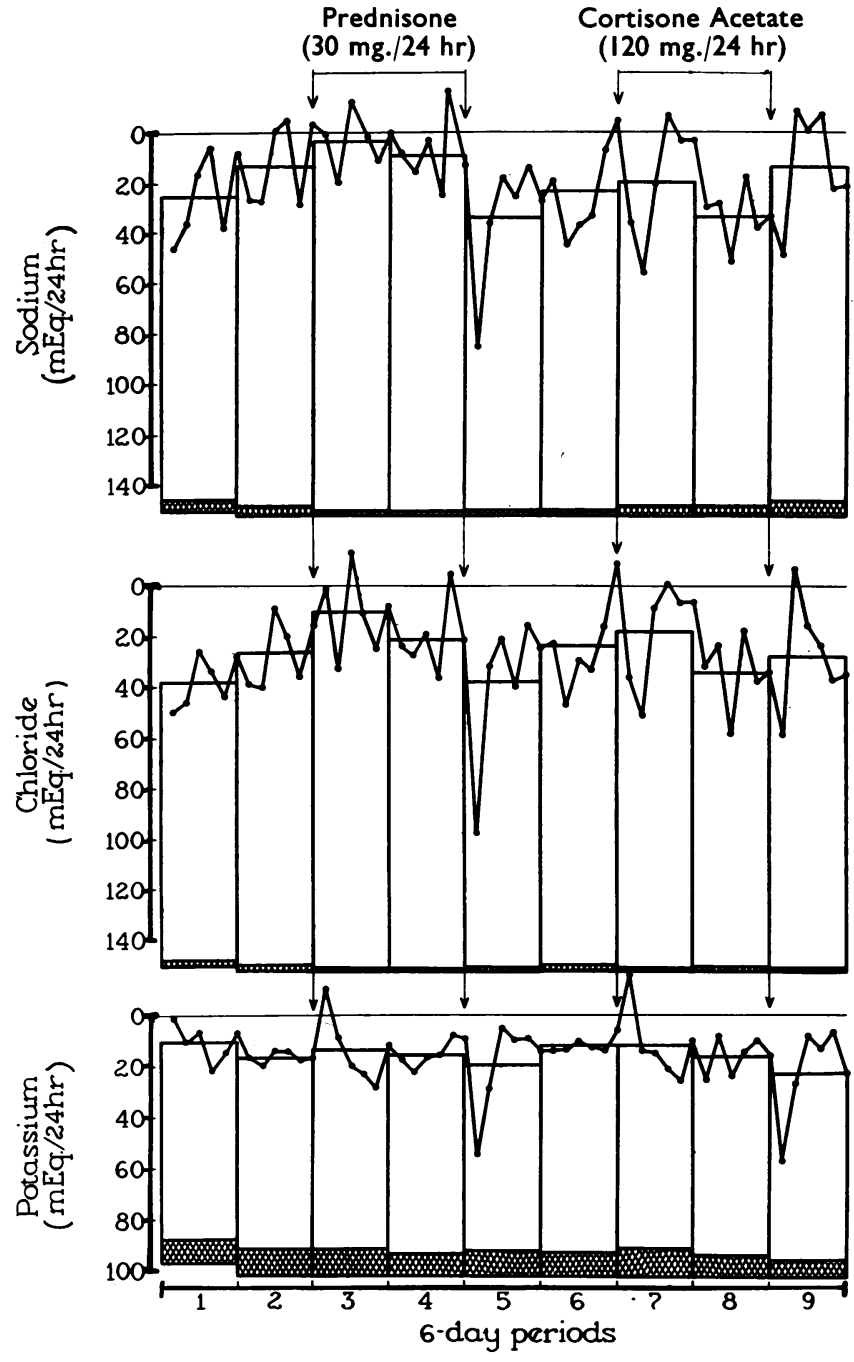

Fig. 6.-Case 2, effect of prednisone and cortisone acetate on balance of sodium, chloride, and potassium.

potential in the production of undesired side-effects. For example, when prednisone was first employed, it was thought to be about three times as potent as cortisone in antirheumatic effect. Doses based on that ratio, instead of the currently accepted ratio of about $4: 1$ or $5: 1$, led to an unexpected increase in some of the unwanted effects. Certain impressions that peptic ulcers are produced or aggravated to a greater extent by prednisone than by cortisone may have arisen, at least partially, because of the use of relatively larger doses of prednisone (Boland, 1956). On the other hand, studies based on the initial information that triamcinolone was about twice as potent as prednisone in antirheumatic effect (Hellman and others, 1957) have already led to mistaken conclusions concerning its freedom from undesired sideeffects, since more recent data suggest that the ratio is more nearly $1: 1$ (Hellman and others, 1957).

Effect on Electrolytes.-Prednisone caused an initial increase in excretion of sodium and chloride, whereas hydrocortisone in Case 1 and, to a lesser extent, cortisone in Case 2 led to retention of these electrolytes. Only prednisone was given in Case 3. Thus, in these short-term studies, the effects of prednisone and those of cortisone or hydrocortisone on sodium and chloride tended to operate in opposite directions. However, although there was a loss of sodium and chloride during the first 2 weeks or so of administration of prednisone, later during treatment these electrolytes tended to be approximately in balance.

Individual differences in the effect of prednisone on the sodium and chloride balances were notable, the excretion of these substances being increased most in Case 1 (20 mg. prednisone per day), less so in Case 3 (30 $\mathrm{mg}$. prednisone per day), and least in Case $2(30 \mathrm{mg}$. prednisone per day).

In Case 1 , a dose of $20 \mathrm{mg}$. prednisone per day produced no effect on the potassium balance, whereas daily administration of $80 \mathrm{mg}$. hydrocortisone caused loss of potassium. Neither $30 \mathrm{mg}$. prednisone nor $120 \mathrm{mg}$. cortisone per day influenced the potassium balance in Case 2. In Case 3, a daily dose of $30 \mathrm{mg}$. prednisone caused slight loss of potassium. These data again illustrate the individual differences in response to prednisone.

Predrisone in these short-term studies caused no significant alterations in the plasma concentration of sodium, chloride, potassium, or carbon dioxide in these three cases, nor did cortisone in Case 2. In contrast, hydrocortisone in Case 1 produced hypochloraemic, hypopotassaemic alkalosis.

These data should not be interpreted to mean that prednisone, when given in large doses for longer periods, cannot cause retention of sodium, chloride, and water or excretion of potassium. In our clinical experience, prednisone or prednisolone in 

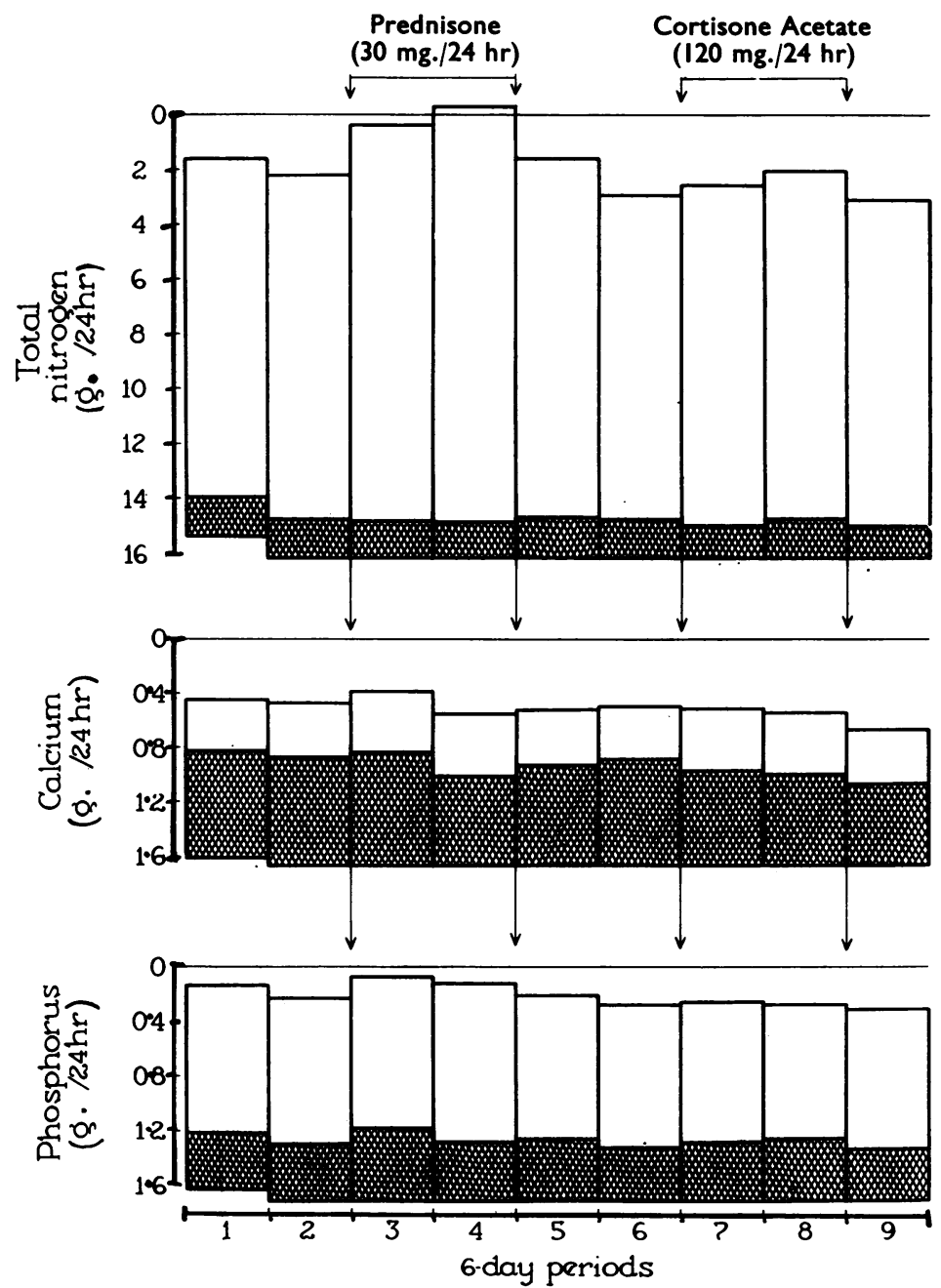

Fig. 7.-Case 2, effect of prednisone and cortisone acetate on balance of total nitrogen, calcium, and inorganic phosphorus.

doses of less than 8 to $10 \mathrm{mg}$. per day generally produces little or no oedema or hypopotassaemia, even when administration is prolonged, but larger doses have produced these effects. Other observers also have reported oedema, retention of sodium, and loss of potassium during administration of prednisone.

As many others have emphasized, the effect of prednisone (Thorn and others, 1955; Dordick and Gluck, 1955; Nelson, 1955) or other corticosteroids on the excretion of sodium reflects the balance between the (usually increased) effects on glomerular filtration and on tubular reabsorption of sodium. Since the relative proportion of these two opposing effects may vary in different patients and diseases, the total effect on the excretion of sodium also may be expected to vary.

Effect on Nitrogenous Substances.-Prednisone, like other $\vec{\Rightarrow}$ antirheumatic steroids, may produce a loss of nitrogen (Thorn and others, 1955; Bunim and others, 1955a; 1955b; Bunim and others, 1955). This effect was pronounced in Cases 2 and 3 क (30 mg. prednisone daily) and less so in Case 1 (20 mg. prednisone daily). Clinical experience suggests that smaller doses of prednisone, such as 5 to $8 \mathrm{mg}$. per day, often do not lead to loss of nitrogen, but may occasionally do so, particularly in postmenopausal women.

The effects of prednisone on $\mathrm{O}$ the nitrogen balance varied not- ably in these three patients and, rather surprisingly, were most $\overrightarrow{\mathrm{D}}$ pronounced in the man (Case 3). It is also noteworthy that, in Case 2, although the steroids were given in comparable antic. rheumatic doses, prednisone pro duced a moderate loss of nitrogen, whereas cortisone caused little loss, if any. However, the effects on nitrogen balance of equivalent antirheumatic doses of prednisone and hydrocortisone were approximately the same in Case 1. These data pointedly indicate the individual variation in response that may be expected from patient to patient.

Prednisone, as well as other antirheumatic steroids, can produce an increase in serum albumin and a decrease in serum globulin. Such changes occurred in Cases 1 and 3 without any change in the total serum protein.

Prednisone, cortisone, and hydrocortisone did not $N$ alter significantly the amount of uric acid in the $N$ serum and urine of these three patients, although larger doses might be expected to increase the urinary excretion of uric acid. None of these steroids affected the concentration of urea in the blood or the urinary excretion of creatinine.

Effect on Calcium and Phosphorus.-Active rheumatoid arthritis may produce osteoporosis and a slightly negative calcium balance; these changes U 


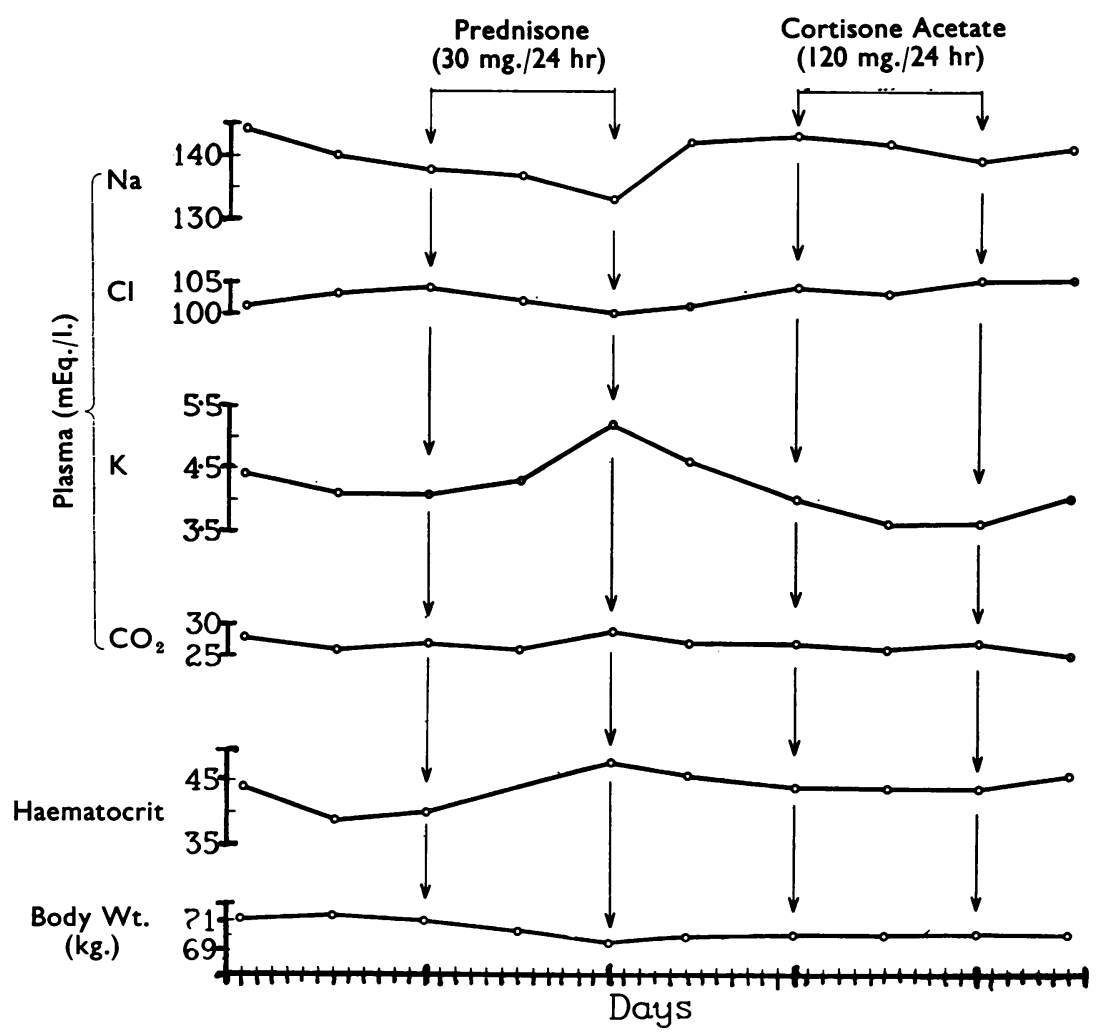

Fig. 8.-Case 2, effect of prednisone and cortisone acetate on concentration of electrolytes in plasma and on haematocrit and body weight.

apparently result not from a primary disturbance of calcium metabolism but rather from a disturbance in protein metabolism and interference with formation of bone matrix (Clark, Bauer, Appleton, and Manning, 1956). Such was apparently so in Cases 1 and 3. The administration of prednisone in these two cases, and of hydrocortisone in Case 1, led to slightly less negative calcium balances, suggesting the possibility of a decrease in the rate of production of osteoporosis, although other metabolic processes, as yet poorly understood, may be responsible for this effect. The calcium balance, initially positive in Case 2, was not appreciably affected by prednisone or cortisone. The concentration of calcium in the serum was not altered by any of the steroids administered to these three patients.

The slight increase in excretion of phosphorus in Cases 2 and 3 was approximately the amount that would be expected in a theoretic phosphorus balance calculated from the nitrogen and calcium balances; thus, it would appear that any tendency for phosphorus to be retained along with calcium was exceeded by loss of phosphorus along with nitrogen from protoplasm. Concentration of inorganic phosphorus in the serum decreased somewhat in all cases during administration of the various steroids.

Effect on Carbohydrate Metabolism.-Although values for blood sugar in the fasting condition were not affected in these three cases, results of the glucose tolerance test became slightly positive (a diabeticlike curve) in Case 2 on a daily dose of $30 \mathrm{mg}$. prednisone but not on a daily dose of $120 \mathrm{mg}$. cortisone. We have observed that prednisone may aggravate the diabetic status, usually only slightly or moderately, in rheumatoid patients who also have diabetes mellitus as others have also noted (Dordick and Gluck, 1955; Bunim and others, 1955; Villa and others, 1955; Cohen and others, 1955).

Effect on Blood Fats.-Administration of prednisone and cortisone or hydrocortisone may increase the blood fats (Bunim and others, 1955a; Dordick and Gluck, 1955; Bunim and others, 1955; Villa and others, 1955; Wang, Bossak, and Adlersberg, 1955; Adlersberg, Schaefer, and Drachman, 1950). This was most apparent in Case 1 , in which the effects of equivalent antirheumatic doses of 


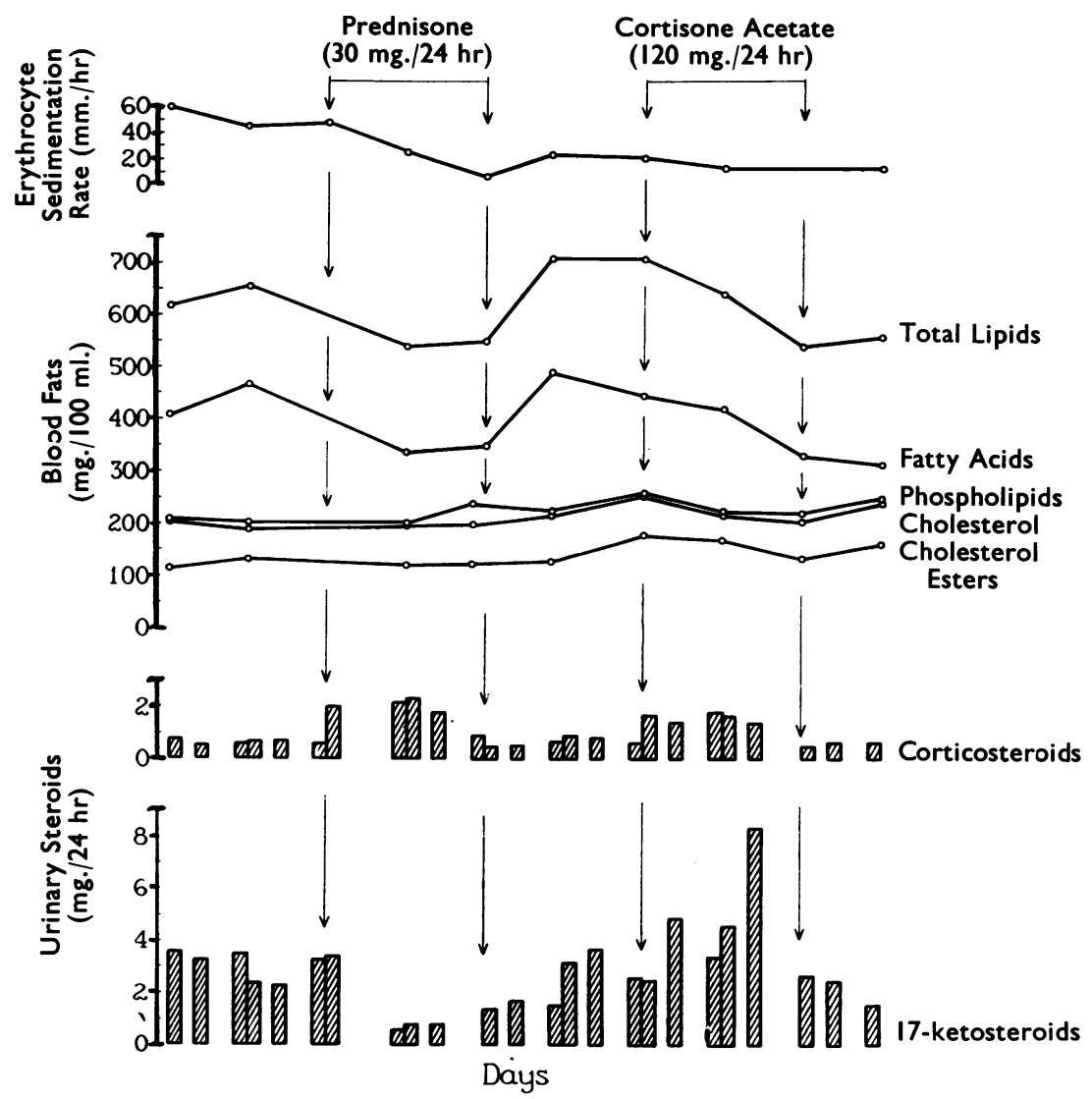

Fig. 9. - Case 2, effect of prednisone and cortisone acetate on erythrocyte sedimentation rate concentration of blood fats, and urinary excretion of corticosteroids and 17-ketosteroids.

prednisone and hydrocortisone produced rather similar increases in blood fats. Again, individual variation was evident, since the effects were less notable in Cases 2 and 3, even though the doses of steroids were greater.

Effect on Circulating Blood Cells.-Prednisone produced changes in circulating blood cells similar to those produced by cortisone or hydrocortisone, namely a tendency to an increase in haemoglobin and neutrophilic polymorphonuclear cells and a decrease in lymphocytes, eosinophils, and basophils (Thorn and others, 1955; Bunim and others, 1955a; Dordick and Gluck, 1955; Villa and others, 1955; Hollander, 1955; Cohen and others, 1955).

Effect on Urinary Excretion of Steroids.-Prednisone decreased the urinary excretion of 17-ketosteroids and increased the urinary excretion of formaldehydogenic corticosteroids in these three patients. This decrease in 17-ketosteroids, also noted by others (Bunim and others, 1955a; Bunim and others, 1955; Villa and others, 1955), suggests inhibition of endogenous pituitary-adrenocortical function by prednisone, as by the other antirheumatic steroids at present available. These data and those on other rheumatoid patients indicate that prednisone given in doses about one-fourth or one-fifth those of cortisone produces equivalent inhibition of pituitary-adrenocortical function, as well as equivalent antirheumatic effects. The increase in corticosteroids in the urine was not necessarily of the same degree in different patients or in the same patient from day to day. Another individual difference was seen in the fact that urinary corticosteroids were increased more in Case 2 by $30 \mathrm{mg}$. prednisone than by $120 \mathrm{mg}$. cortisone, whereas urinary corticosteroids in Case 1 were increased more by $80 \mathrm{mg}$. hydrocortisone than by $20 \mathrm{mg}$. prednisone.

Effect on Basal Metabolic Rate, Electrocardiogram, and Electro-encephalogram.-Prednisone caus- 


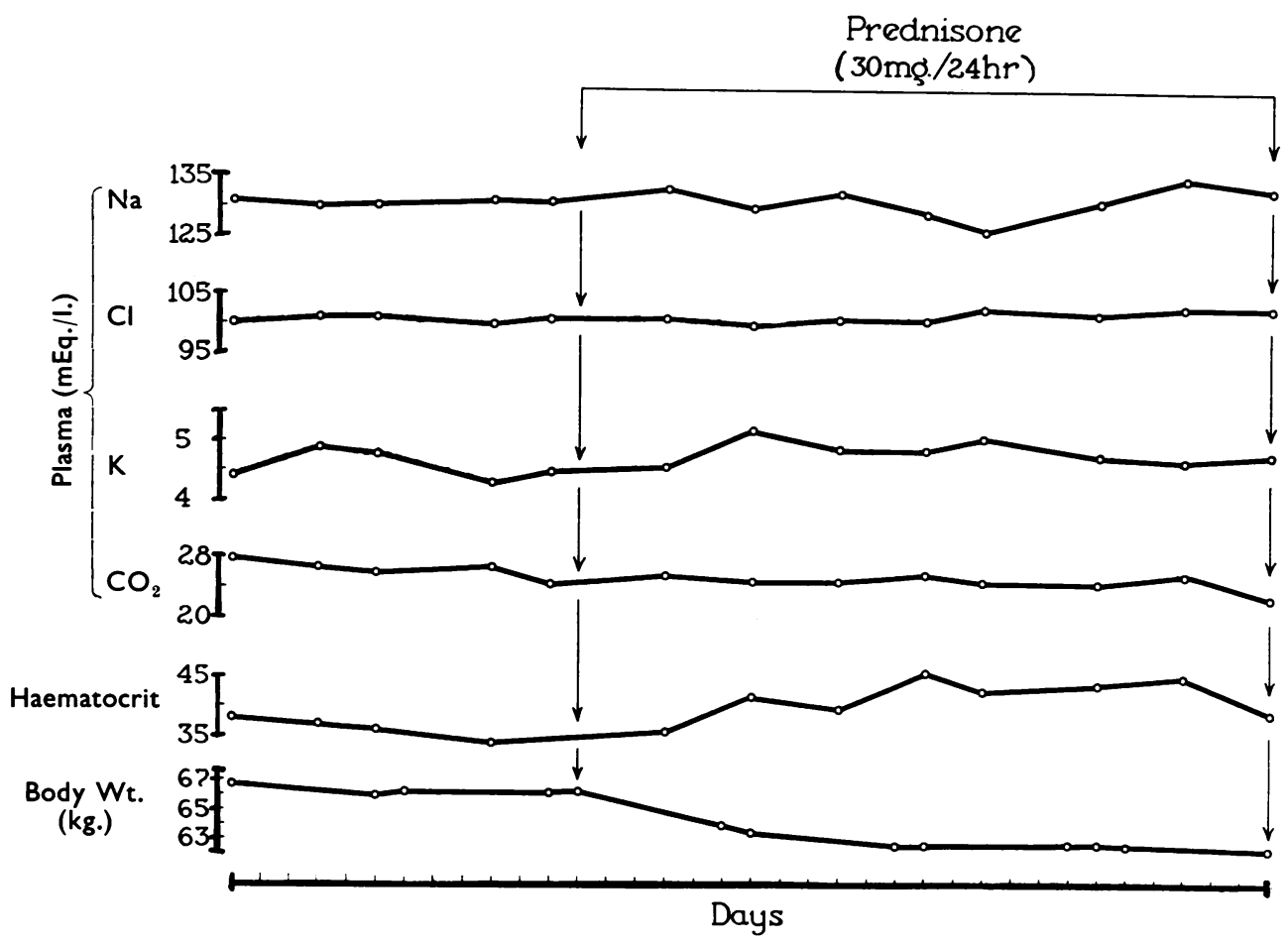

Fig. 10.-Case 3, effect of prednisone on concentration of plasma electrolytes and on haematocrit and body weight.

ed a decrease of no apparent significance in the basal metabolic rate, as has been noted previously during use of cortisone or hydrocortisone (Sprague and others, 1950). Such decreases have been attributed to improvement in the rheumatoid arthritis as well as to more direct but less certainly defined effects on the metabolism of the thyroid gland and its hormone (Sprague and others, 1950; Thorn, Jenkins, Laidlaw, Goetz, Dingman, Arons, Streeten, and McCracken, 1954). Prednisone did not alter the electroencephalograms or the electrocardiograms, although hydrocortisone-induced hypopotassaemia led to lowered $\mathrm{T}$-waves in the electrocardiogram of one patient (Case 1).

\section{Comments on Clinical Use of Prednisone and Prednisolone in Rheumatic Diseases, especially Rheumatoid Arthritis}

Prednisone and prednisolone, like their predecessors, cortisone and hydrocortisone, are useful antirheumatic steroids. Their lessened effect on electrolytes is especially advantageous for patients who have a tendency to retain fluid or lose potassium, or for patients who require comparatively large doses of an antirheumatic steroid, as in acute rheumatic fever or a severe flare of systemic lupus erythematosus. However, previously available steroids such as cortisone or hydrocortisone, as we used them (Ward, Polley, Slocumb, and Hench, 1953; Hench and Ward, 1954), seldom caused serious or uncontrollable disorders in electrolytes when the doses employed for prolonged treatment of uncomplicated rheumatoid arthritis were small enough to avoid other manifestations of hypercortisonism. In respect to the production by overdosage of other undesirable effects, such as obesity, supraclavicular fat pads, hypertrichosis, acne, psychic changes, osteoporosis, peptic ulcers, striae, purpura, and hypertension, prednisone and prednisolone are generally similar to cortisone or hydrocortisone in equivalent antirheumatic doses.

The use of prednisone or prednisolone in rheumatoid arthritis requires the same general precautions as the use of cortisone or hydrocortisone (Ward and others, 1953; Hench and Ward, 1954):

(1) A clear-cut indication must exist for their use, such as active rheumatoid arthritis not satisfactorily managed by physical therapy, salicylates and rest, or, in some cases, gold. 

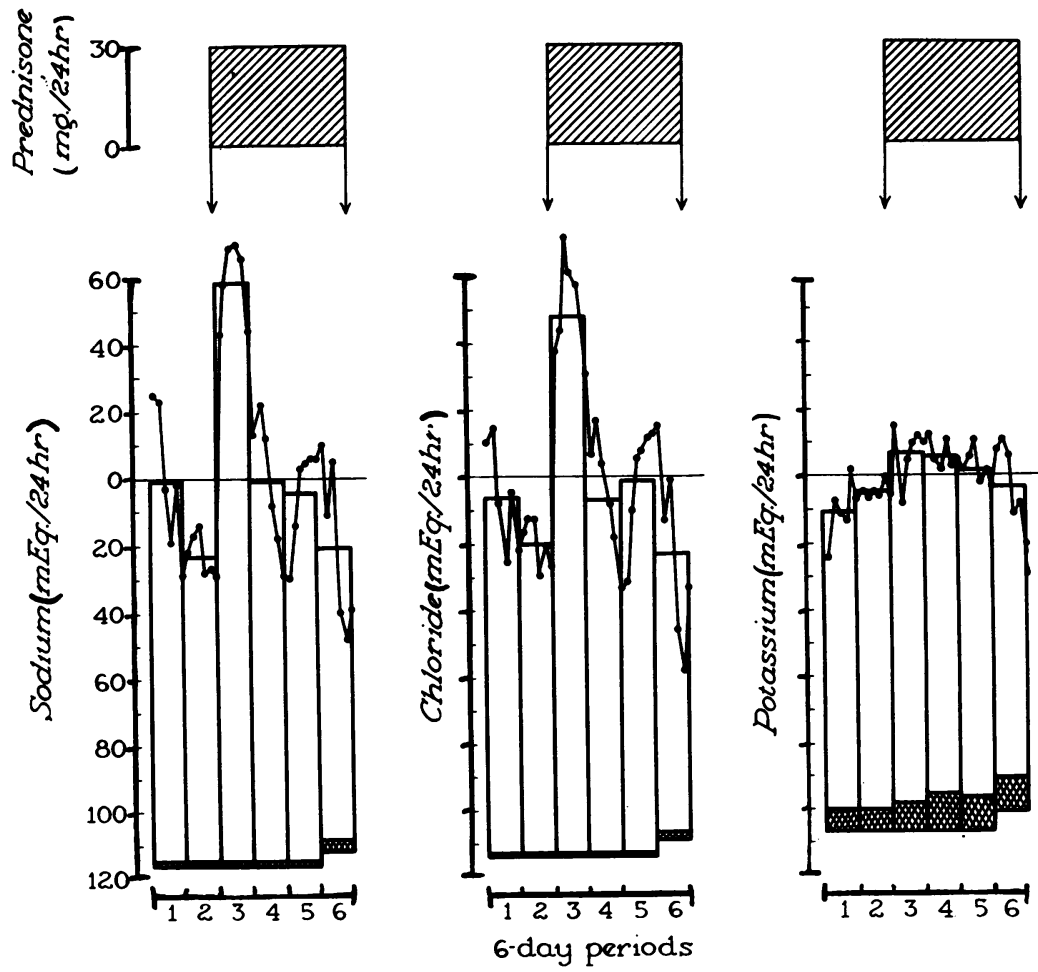

Fig. 11.-Case 3, effect of prednisone on balance of sodium, chloride, and potassium.

(2) Before treatment, a careful medical examination should be performed, with particular emphasis on those special features of the history, physical examination, and laboratory studies that are capable of uncovering potential conditions which might contraindicate or complicate the use of steroidal therapy.

(3) The physician should recheck the patient at frequent intervals to evaluate his progress, to regulate dosage, and to note and care for any side-effects or impending complications (Hench and Ward, 1954). In lieu of oedema as an early manifestation of hypercortisonism, the physician must watch for other signs, such as mental stimulation, increased appetite, gain in weight beyond the patient's predisease weight, slight facial hypertrichosis, minor degrees of facial rounding and supraclavicular fat pads, increase in blood pressure, and menstrual irregularities or increased menopausal symptoms.

(4) Doses should be measured individually to provide an optimal antirheumatic effect without hypercortisonism. Not only the total 24-hr dose, but also each 6-hr or 8-hr dose should be adjusted to fit each particular case. Individual requirements and tolerance for prednisone or prednisolone, like those for other antirheumatic steroids, may vary considerably. Hypercortisonism will develop in many instances during prolonged administration of prednisone or prednisolone if the doses shown in Table II are exceeded or, in some cases, even maintained.

TABLE II

UPPER LIMIT OF MAINTENANCE DOSES OF STEROIDS IN RHEUMATOID ARTHRITIS

\begin{tabular}{|c|c|c|c|}
\hline \multirow{2}{*}{ Patients } & & Dose (mg.)* & \\
\hline & Cortisone & $\begin{array}{l}\text { Hydro- } \\
\text { cortisone }\end{array}$ & $\begin{array}{l}\text { Prednisone or } \\
\text { Prednisolone }\end{array}$ \\
\hline Postmenopausal Women & 30 & 25 & 6 \\
\hline Premenopausal Women & 40 & 35 & 8 \\
\hline Men & 50 & 45 & 10 \\
\hline
\end{tabular}

* In most cases, the doses should be slightly less than these.

It is generally better to start with doses within a reasonable range for prolonged administration than to $\omega$ give large initial doses. If hypercortisonism develops $\sigma$ during treatment, the dose should be decreased graduallyco to permit disappearance of the manifestations of over- $\frac{\bar{D}}{\mathrm{D}}$ dosage. Several days or even a week or more should be? allowed between decreases in dosage to permit the $\square$ patient to adjust himself to the new dosage; reductions $\overline{0}$ usually should be small, not exceeding 0.5 to $1 \mathrm{mg}$. at $\overrightarrow{\mathbb{D}}$ 

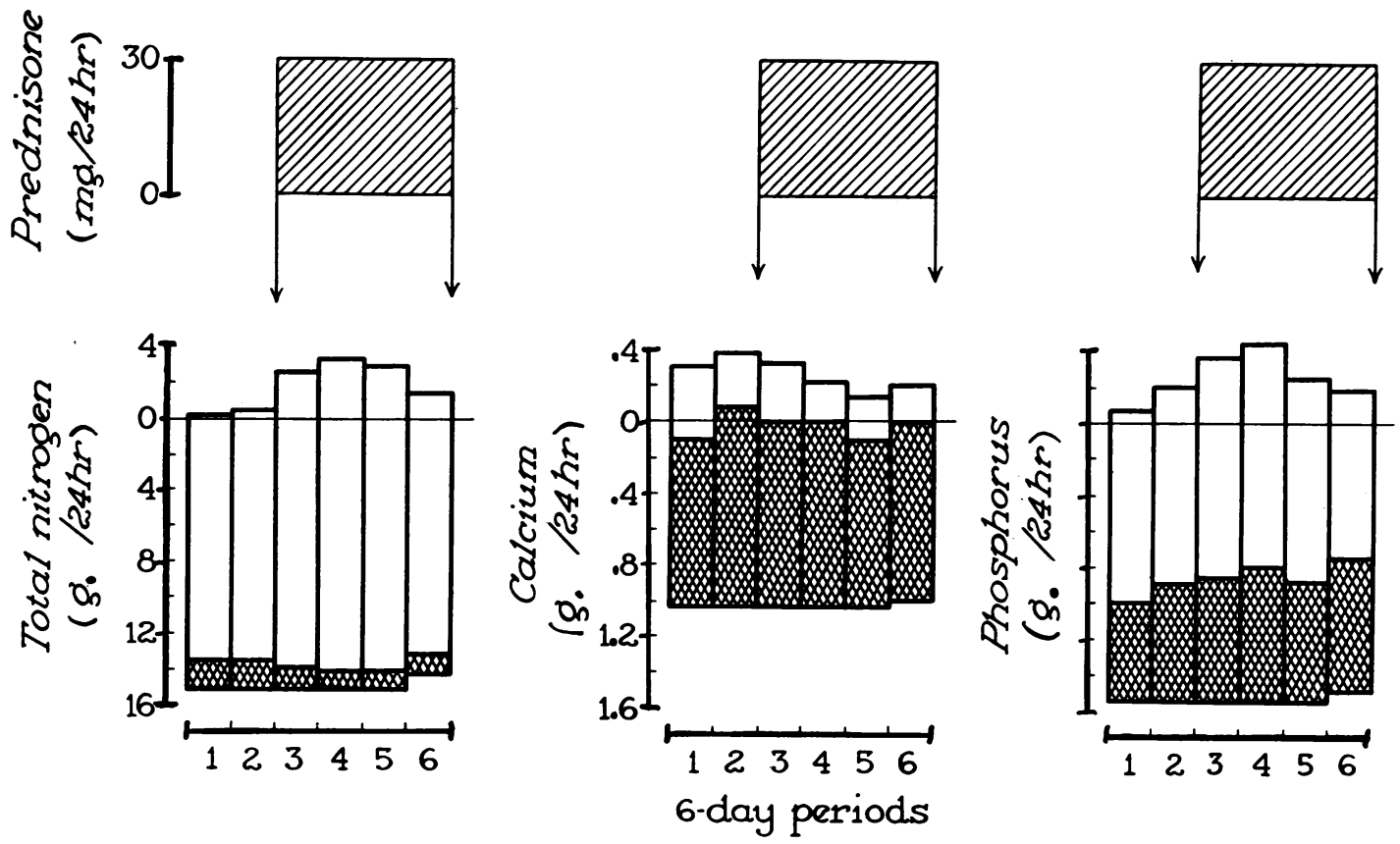

Fig. 12.-Case 3, effect of prednisone on balance of total nitrogen, calcium, and inorganic phosphorus.

a time. The daily dose of the steroid must be divided into at least three, and sometimes four, parts, administered regularly every 6 or $8 \mathrm{hrs}$. Some variation in the size of these individual doses during the 24-hr period is often necessary to meet the particular needs of the patient (Hench and Ward, 1954). Dosage schedules should be sufficiently flexible to permit the intelligent, co-operative patient to select, within certain prescribed limits, a slightly larger dose for days when symptoms are worse and a slightly smaller dose for "good" days. Eventual discontinuation of steroidal therapy by gradual reduction of dose is desirable when possible.

(5) In the event of unusual stress, such as a major operation, serious infection, or severe trauma, supplementary amounts of cortisone or hydrocortisone should be administered and other special precautions should be taken to avoid the consequences of pituitary-adrenocortical insufficiency (Hench and Ward, 1954).

(6) Treatment of rheumatoid arthritis with prednisone or prednisolone (as well as with cortisone or hydrocortisone) should be supplemented by other appropriate measures, such as physical therapy, salicylates, and rest. Salicylates, useful not only for their analgesia but also for their apparent mild anti-inflammatory effect, should be given to the limits of optimal relief and comfortable tolerance, and their administration should be continued at such limits even when rheumatoid symptoms are improving and the dose of the antirheumatic steroid is being reduced.

\section{Summary}

Prednisone (or prednisolone) given to patients who have rheumatoid arthritis produces similar effects to those produced by cortisone or hydrocortisone with respect to antirheumatic action, influences on the metabolism of nitrogen, carbohydrate, and fat, suppression of pituitary-adrenocortical function, and influences on blood cells and the basal metabolic rate.

However, two important differences are noteworthy:

(1) Prednisone is at least four or five times as potent as cortisone or hydrocortisone, milligram for milligram, both in antirheumatic effects and in most of the metabolic effects studied to date, except those relating to electrolytes;

(2) Prednisone has relatively less effect on the metabolism of electrolytes and hence produces less retention of sodium, chloride, and water, and less excretion of potassium, in comparison with cortisone or hydrocortisone in equivalent antirheumatic doses.

The clinical use of prednisone or prednisolone must be attended by the precautions previously established for the optimal use of cortisone or hydrocortisone, namely careful selection of patients, proper medical supervision during treatment, 


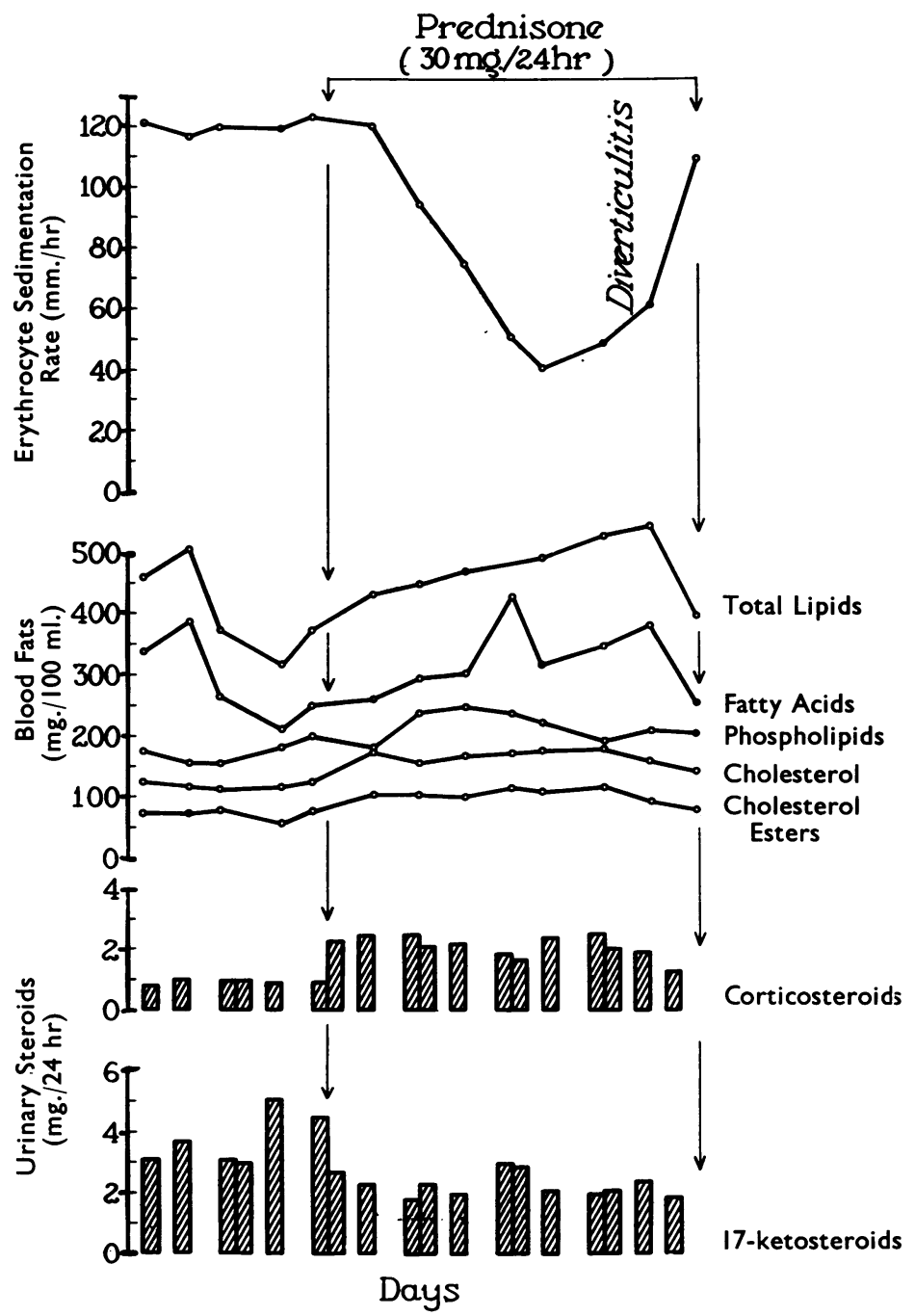

Fig. 13.-Case 3, effect of prednisone on erythrocyte sedimentation rate, concentration of blood fats, and urinary excretion of corticosteroids and 17 -ketosteroids.

individual dosage schedules to provide optimal antirheumatic effects without hypercortisonism, special precautions at times of increased stress, and appropriate supportive and supplementary therapy.

The synthesis of these new cortisone-like steroids, prednisone and prednisolone, like that of fludrocortisone, is of great importance in providing further evidence that the basic structure of cortisone can usefully be altered.

\section{REFERENCES}

Adlersberg, D., Schaefer, L., and Drachman, S. R. (1950). J. Amer. med. Ass., 144, 909.

Boland, E. W. (1955). California Med., 82, 65.

Boland, (1956). J. Amer. med. Ass., 160, 613.
Bunim J. J. (1957) "Indications for and the Choice of Adrenal Corticosteroids in the Management of Rheumatoid Arthritis." Read at the meeting of the American College of Physicians, 0 Read at the meeting of the American College of Physicians,
Boston, Massachusetts, April 8 to 12,1957 . N.Y. Acad. Sci., 61, art. 2, p. 358 .

Pechet, M. M. and Bollet, A. J. (1955a). J. Amer med Ass O $157,311$.

_ 1955b). Ann. rheum. Dis., 14, 102.

Clark, W. S., Bauer, W., Appleton, J., and Manning, E. (1956). $\mathrm{W}$ Acta rheum. scand., $2,193$.

Cohen, A., Turner, R., and Dunsmore, R. (1955). New Engl.J. Med., 253,1150 .

Dordick, J. R., and Gluck, E. J. (1955). J. Amer. med. Ass., 158, 166. 을 Glenn, E. M., Stafford, R. O., Lyster, S. C., and Bowman, B. J. (1957). Ann. rheum. Dis., 16, 139.

Hellman, L., Zumoff, B., Schwartz, M. K., Gallagher, T. F., Berntsen, C. A., and Freyberg, R. H. (1957). Ibid., 16, 141.

Hench, P. S., Kendall, E. C. Slocumb, C. H., and Polley, H. F. (1949)

-_, Proc. Mayo Clin.,24, 181. 
Hench, P. S. and Ward, L.E.(1954). "Rheumatoid Arthritis and Other Rheumatic or Articular Diseases." In F. D. W. Lukens: "Medical Uses of Cortisone: Including Hydrocortisone and Corticotropin", pp. 177-275. Blakiston, New York Hollander, J. L. (1955). The Merck Report, 64, no. 4, p. 3

Margolis, H. M., Barr, J. H., Jr., Stolzer, B. L., Eisenbeis, C. H., Jr., and Martz, E. W. Jr, (1955).J. Amer med. Ass., 158, 454.

Nelson, C. T. (1955). J. invest. Derm., 24, 377

Salassa, R. M., Power, M. H., Ulrich, J. A., and Hayles, A. B. (1954). Proc. Mayo Clin., 29, 214.

Spies, T. D., Stone, R. E., Garcia López, G., Díaz Tellechea, C. M., López Toca, R., Reboredo, A., and Suárez, R. M. (1955). J. Amer. med. Ass., 159, 645 .

, J. And Spies, H. A., Jr. (1955). Gen. Pract. Clin., 12, 73. , R. G., Power, M. H., Mason, H. L., Albert, A., Mathieson D. R., Hench, P. S., Kendall, E. C., Slocumb, C. H., and Polley, H. F. (1950). Arch. intern. Med., 85, 199.

Thorn, G. W., Jenkins, D., Laidlaw, J. C., Goetz, F. C., Dingman, J. F., Arons, W. L., Streeten, D. H. P., and McCracken, B. H (1954). "Pharmacologic Aspects of Adrenocortical Hormones in Man, and Their Effects in Adrenal Insufficiency." In F. D. W. Lukens: "Medical Uses of Cortisone: Including Hydrocortisone and Corticotropin", p.80. Blakiston, New York.

_, Renold, A. E., Morse, W. I., Goldfien, A., and Reddy, W. J. (1955). Ann. intern. Med., 43, 979.

Villa, L., Ballabio, C. B., and Sala, G. (1955). Ann. rheum. Dis. $14,251$.

Wang, C.-I., Bossak, E. T., and Adlersberg, D. (1955). J. clin. Endocr., 15, 1308.

Ward, L. E., Polley, H. F., Slocumb, C. H., and Hench, P. S. (1953). J. Amer. med. Ass., 152, 119

M Mason, H. L., Mattox, V. R., and Power, M. H. (1954). Proc. Mayo Clin., 29, 649.

\section{La prednisone dans l'arthrite rhumatismale: effets} cliniques et métaboliques

\section{RÉSUMÉ}

La prednisone (ou la prednisolone) administrée aux malades atteints d'arthrite rhumatismale a la même action que la cortisone ou l'hydrocortisone en ce qui concerne l'effet antirhumatismal, le métabolisme azoté, hydrocarboné et lipide, la suppression de la fonction surréno-cortico-pituitaire et l'influence sur les globules sanguins et le métabolisme basal.

On note, cependant, deux différences importantes:

(1) La prednisone, à poids égal, est au moins quatre ou cinq fois plus puissante que la cortisone ou la hydrocortisone en ce qui concerne son action antirhumatismale et ses effets métaboliques étudiés, à l'exception de ceux sur les électrolytes.

(2) L'effet de la prednisone est relativement moindre sur le métabolisme des électrolytes; la rétention sodique, chloruré et aqueuse, ainsi que l'excrétion potassique sont, par conséquent, moins prononcées qu'avec la cortisone ou l'hydrocortisone à doses antirhumatismales égales.
En clinique, la prednisone ou la prednisolone exigent les mêmes mesures de précaution que la cortisone ou l'hydrocortisone, c'est-à-dire une sélection soigneuse des malades, surveillance médicale étroite pendant le traitement, administration adaptée aux besoins du malade individuel, de manière à obtenir un effet antirhumatismal optimum sans hypercortisonisme, soins spéciaux en temps de tension augmentée et thérapie supplémentaire et de soutien appropriée.

La synthèse des stéroides genre cortisone, tels que la prednisone, la prednisolone et la fluorocortisone est importante car elle montre que la structure essentielle de la cortisone peut être modifiée avantageusement.

\section{La prednisona en la artritis reumatoide: efectos clínicos y metabólicos}

\section{Sumario}

La prednisona (o la prednisolona), administrada a enfermos con artritis reumatoide, se parece a la cortisona o la hidrocortisona en su efecto antirreumático, sobre el metabolismo nitrogenado, hidrocarbonado y lípido, sobre la supresión de la función suprarreno-córticopituitaria y en su influencia sobre los glóbulos sanguíneos y el metabolismo basal.

Se notan, sin embargo, dos diferencias importantes:

(1) La prednisona, a peso igual, es al menos cuatro o cinco veces más poderosa que la cortisona o la hidrocortisona en su acción antirreumática, así como en sus efectos metabólicos estudiados, con excepción de los efectos sobre los electrolitos.

(2) El efecto de la prednisona es relativamente menor sobre el metabolismo de los electrolitos; la retención sódica, clorurada y acuosa, así como la excreción potásica son menores que con la cortisona o hidrocortisona en dosis antirreumáticas iguales.

En clínica, la prednisona o la prednisolona exigen la misma cautela que la cortisona o la hidrocortisona, quiere decir, una selección cuidadosa de enfermos, vigilancia médica apropiada del tratamiento, administración adaptada a las necesidades individuales para obtener un efecto antirreumático óptimo sin hipercortisonismo, cuidados especiales en tiempo de tension aumentada y terapia suplemental y de soporte apropiada.

La síntesis de esteroides del tipo de cortisona, como la prednisona, la prednisolona y la fluorocortisona es importante, por demostrar que la estructura esencial de la cortisona se puede modificar provechosamente. 